\title{
RESEARCH ON PUBLIC LOGISTICS CENTRE AS TOOL FOR COOPERATION
}

\author{
Andrius Jaržemskis \\ Transport Research Institute, Vilnius Gediminas Technical University, Plytinès g. 27, \\ LT-10105 Vilnius, Lithuania.Phone: +370 5 2370605.E-mail:andrius.j@ti.vtu.lt
}

Received 15 July 2006; accepted 4 December 2006

\begin{abstract}
This paper focuses on logistics centre concept and benefits for users. Intermodal benefit, forwarders impact, IT solutions, new transport flows due to synergy, better supply chain management, additional services, cost sharing, economies of scale, quality of the services, know-how, joint marketing impact, and benefit for growth of third-party logistics services are presented. The main bottlenecks such as duration of planning logistics centres process, pressure to land use for other purposes and problems caused by legislation are described. Results of pilot study of benefits from business cooperation are presented and concluded as well.
\end{abstract}

Keywords: logistics centre, intermodality, concentration of the services.

\section{Introduction}

In Europe we meet many terms such as "Centres logistiques de fret", "Gares routières de merchandises", "Logistics park", "Platform freight terminal", "Interporto", "Centro integrado de mercancias", "Güterverkehrzentrum", "Transport centre", "Freight village", "Transport center". These terms generally define a logistics centre. Many warehouses or terminals are also called logistics centres by their owners. The name Logistics centre as a marketing element is used by many transport and logistic companies. The aim of this article is to denote the concept of a logistics centre, present advantages and bottlenecks for their establishment in new EU countries. Establishment of logistics centres especially in new EU countries is difficult for many reasons. Wrong understanding of its concept is one of these as well.

The logistics centre concept is very well presented by Kent Bentzen [1] as a centre in a defined area within which all activities relating to transport, logistics and the distribution of goods - both for national and international transit, are carried out by various operators on a commercial basis. The operators can be either owners or tenants of buildings and facilities (warehouses, distribution centres, storage areas, offices, truck services, etc.), which have been built there. In order to comply with free competition rules, a logistics centre must be open to allow access to all companies involved in the activities set out above. A logistics centre must also be equipped with all the public facilities to carry out the above-mentioned operations. If possible, it should include public services for the staff and equipment of the users. In order to encourage intermodal transport for the handling of goods, a logistics centre should preferably be served by a multiplicity of transport modes (road, rail, deep sea, inland waterway, air). To ensure synergy and commercial cooperation, it is important that a logistics centre is managed by a single and neutral legal body preferably by a Public-Private-Partnership.

The logistics centre concept is based on three important elements which in turn generate other relevant effects on economics and transport standpoints [2].

Territorial planning alongside infrastructure rationalization. Dedicating a specific area to transport, logistics and goods distribution automatically implies planning the territory and rationalizing infrastructure in order to optimize area utilization, to safeguard the environment, moving the heavy traffic concerned from residential areas to the logistics centre and to build the infrastructures following specific criteria based on operator necessities.

Transport quality. Globalisation, the growth of the trade and growing competition between all local production areas have been forcing industries to ask for more efficient transport and logistics solutions. Optimization of the logistics chain, of transport means utilization, of warehouse utilization, of manpower organisation generate decrease in the total transport costs, in the total industrial costs and in personnel costs.

Intermodality development. Road transport is still the most useful transport mode in Europe. According to the White Paper [3], the demand for road transport has been constantly increasing over the last 20 years, against a steady decrease in rail freight transport. One of the aims of a logistics centre is promotion of due convenient transport and synergic solutions to transfer more traffic to railway and short sea shipping in EU. An offer of block shuttle trains for long-range journeys is the way for better performance. 
Location is a key factor for all the transport operators [2, 4-7]. Reduction of the delivery time to the final destination or to the following passage of the logistics/transport chain is one of the elements that could make an important difference when a transport operator is being chosen. Assuring fluidity between all the transport connections and coordinating all the transport modes are some of the tasks of a logistics centre. Most European logistics centres are located in hub points for transport and distribution activities. Location in a hub point means, in short, being near the main railway, motorway and seaway arteries.

\section{The possible benefit of the cooperation within logistics centres}

Intermodality benefit [8-10]. Logistics centre should suggest more multimodality solutions, especially increasing of the sea and inland waterway transportation. The direct multimodality benefits will be accepted by loading companies, terminal owners and forwarders. The effect should increase the volume of goods. Interaction of different transport modes according to good experiences of other EU countries gives a better transport performance and reduces costs in such cases as using shuttle trains for trailers and containers. For establishment of multimodal transport chains it is necessary to consider the synergy effect and satisfied goods turnover. Small companies could not reach this alone. A logistics centre is the best way for liquidation of the mentioned "bottleneck". The integration of different modes of transport into a logistics centre should increase frequency of the transportation which is important from the customer point of view.

Forwarders impact. In many cases forwarders will be first who directly contact a customer. Forwarders involvement in logistics centre activity is one of the synergy impacts. Forwarder work within logistics centre should increase the flexibility of the whole system.

IT Solutions. Many transport and warehousing companies are small, and use no special IT software for operation management. The cargo turnovers of these companies are too small for IT solutions. Logistics centres could play the consolidation of turnovers role and due to economies of scale the companies can get possibility for more efficient operation planning and control. IT solutions should have a strong impact on attraction of world-class manufacturer to establish distribution warehouses in the logistics centre. IT solutions play an important role in planning, executing and control of transportation, warehousing and settlement process.

New transport flows due to synergy. Synergy effect will be one of the reasons for the growth of cargo volumes. Logistics centres will provide a service complex of world class quality. Warehousing capacity and modern equipment possible should attract "new goods" - world class companies for their products distribution. New warehousing and distribution capacities should give positive impact on the growth of domestic transportations. Turnover for forwarders, carriers, insurance companies, freight operators and loading companies will grow-up for "new goods".

Supply chain management. Individual transportation and warehousing firms today are not attractive for world class manufacturing and trading companies for the poor service level and extremely low warehouse capacity. Supply Chain Management System requires for integrated services, such as cooperative planning, transport planning, E-Procurement, Warehousing, Deployment. Separate individual companies today can not offer such services and lose potential customers. Logistics centre could be a strong element in the supply chain.

Additional services. Synergy effect which will increase goods volume could be additional service to providers in logistics centres. Customs infrastructure, postal/bank/insurance services, rent of offices, intermodal terminals, warehouses, filling stations, washing facilities, packaging, customs clearance, research activities should attract many entrepreneurs to logistics centres. Centralised electric supply and electric appliances, telecommunication service should reduce costs of separate companies within logistics centres.

Cost sharing. Cost sharing will play an important role in benefit of logistics centre service providers. Sharing storage facilities, IT-systems, service development and knowledge give big advantages for higher profits margin.

Economies of scale. Economies of scale through co-operation with other logistics centres will focus on transportation companies as primary. Hub-spoke principles in freight transportation will allow to decreace the quantity of transport links and to ensure better quality of them. Carriers should get the possibility to provide long-term services for logistics centres. Long-term transportation tenders are the advantage for carriers. Better planning of activity, using of transport means, improving the management of allotment of transport fleet are main priorities for that.

Quality. Quality standard for companies involved in logistics centre activity should be one of active marketing elements. For customers' decisions an image of service providers is very important. Working of the company within logistics centre should be "quality mark".

Know-how. Big transport companies mostly have possibility to keep the best managers who plan, perform and control their activity. Small and medium sized companies, conversely have less chance to have world class managers on board due to high compensations. In logistics centres know-how of performance and control could be distributed among local experts of logistics centre.

Joint marketing. The companies which work within logistics centre could provide joint marketing. It is an advantage for small companies especially, which have no financial possibility for their own marketing.

3PL. Logistics centre is a perfect condition for third-party logistics service providing. Trading companies should reject their own warehouses especially in the city centres for better performance in logistics centres [11]. 


\section{Bottlenecks of logistics centres establishment in new EU countries}

The catalyst of logistics centre establishment is attracting of public capital, funds or financial investors to logistics and transport business. For this reason it is necessary to replace part of the fixed capital in the transport sector with a floating capital base. Many road carriers and forwarders in new EU countries such as Lithuania are limited and owned by one or few promoters. Main shareholders mostly are top managers of these companies. The reason for that is that owners and managers of these companies are businessmen of first generation and they try to keep the control of the selfestablished companies. They have strong mentality as transport specialists. Growth of their created companies without external investment is the essence of their professional activities in many cases. Small transport companies should be target groups as potential companies involved in the logistics centre activity. Logistics centre will give possibility to survive for small and medium business in the future.

One of the unsolved questions is pricing policy of the services provided in logistic centres. In case when logistics centre services are provided by several separate companies the pricing-conflict could spring-up on two levels. First, when homogenous services are provided by several companies and second, when heterogeneous services are provided by separate companies, e.g. one company - loading, another - storage service, next - transportation etc. Pricing conflict in competition between homogenous service providers could come at first because of different costs and different profit margins of these. Price competition inside a logistics centre could influence negative relationship between operators.

Pricing conflict could come between heterogeneous services. Customers could expect many different services in the logistics centre, such as warehousing service, insurance broker's service, customs broker's service, transportation, consulting, loading, packing, marking, selecting and distributing, regular just-in-time delivery by small volumes over a short distance, etc. Customers will purchase only one of the mentioned services rarely. Customers need in many cases a service complex. They require a common service packet including several activities. Competitive service price is one of the meanest purchasing factors in East-side of the Baltic region. For the reason of economies of scope a logistic centre could satisfy this factor. For the client the total price of service packet plays a significant role. Separate service tariffs are not a part of making a decision in this case. To fix a high price of one part of the service could make the total price non-competitive. Some service providers could get strong pressure to decrease their price for common success (e. g. port and railway interaction in Lithuania). When a loading company increases their tariffs the total transit service prices become ineffective in comparison with other transit paths. For better performance a loading company makes pressure to railway to decrease railway tariffs for transit via port. Inter-competition with an idea "who first give-up" is undesirable in a logistics centre.

The three following barriers could be expressed like preparation stage barriers [12]. One of the barriers is duration of planning process. Spatial planning takes too long and investor may lose money in case when the planning procedure is prolonged. For the establishment of a logistics centre first selection of specific location for the future investment is necessary. Later it is necessary to determine if the terrain for the future investment is already a part of the local development plan and allows the realisation of the planned logistic centre investment. The next step is acquisition of legal rights to the terrain and only then the actual investment can be made. If there is no local spatial plan, investor should appeal to the local authorities making an application that includes characteristic of the future investment. In that case the local spatial plan will be created.

The second barrier is pressure to land use for other purposes. One aspect of this problem is connected with the expansion stage of logistic centres development and competition for land use. Settlement, recreation and nature conservation areas may also exist near the logistics operations areas. This may cause problems to acquire new areas for logistics activities.

The third kind of problems is caused by legislation. Heavy bureaucracy, long procedures are enabled by law. Everyone involved in the spatial planning process may complain and therefore in practise delay the plan from coming into force even for years.

In new EU countries the opposing side are often ecologists who on the basis of the environmental protection law can even stop the whole investment process. Another problem is instability of law and procedures. The validation of legal acts is too short if compared with duration of logistics centre planning and establishment process. Changes of legal acts could stop the started process. In such countries as Lithuania repatriation of land is not a solved question, and it is impossible to provide spatial planning of terrain without claims.

Lack of coherent national transport policy, which would include logistics issues and lack of long-term governmental strategy for the development of national macro-logistics network, based on intermodal logistics networks stop the creating process of the logistics centre.

Many bottlenecks are related to private and public partnership in financing skill especially:

- the public and private partnership in new EU countries experience lack of relevant regulations;

- different expectations of the public and private sectors regarding the creation of logistics centres are met, e.g. unrealistic expectations on the part of the public sector, regarding the quick and trouble-free returns from investments in logistics centres;

- lack of knowledge regarding the possibilities of financing investments in the framework of publicprivate partnership (national and EU funds) and regarding the rules of cooperation between the public and private sectors, resulting from the financial regulations 
of the EU and regarding popular options of financing investments by banks and financial institutions.

In realisation process there is a lack of understanding of the need for the leadership of the public sector in the initial phase of the investment and the knowledge of roles and tasks in that period.

Some errors during the preparation phase like publicity for the idea before preparation of conditions for its realisation, ill-prepared contracts with investors and lack of collaboration during the planning stage between the institutions of the public sector and state-owned companies which should be partners in realisation are also strong barriers for the establishment of logistics centres.

\section{Results of pilot survey in Lithuania}

The pilot study of selected eleven Lithuanian small and medium sized transport/logistics companies was done for evaluation of the possible business cooperation advantage within logistics centre factors. The survey was done by the author of the article within BSR Interreg III B project INLOC (Integrating Logistics Centre in the Baltics Sea Region). Eleven selected transport companies were the respondents.

The respondents were asked to answer the following questions as follows: strongly agree (evaluated -5 ), agree (4), neutral (3), disagree (2), strongly disagree (1). The top four answers to each question and their average rates are presented in Tables 1-5.

Table 1. Motives for cooperation with the same type of business companies

\begin{tabular}{|l|l|}
\hline Economies of scope & 4.0 \\
\hline Need for resources & 4.1 \\
\hline Economies of scale & 3.8 \\
\hline Risk limitation & 3.7 \\
\hline
\end{tabular}

Table 2. Benefits / profits from cooperation with the same type of business companies

\begin{tabular}{|l|l|}
\hline $\begin{array}{l}\text { Multimodal benefits-interaction of different trans- } \\
\text { port modes }\end{array}$ & 4.4 \\
\hline Growth of cargo volumes & 4.1 \\
\hline New additional services & 4.0 \\
\hline Increased competitiveness & 4.0 \\
\hline
\end{tabular}

Table 3. Financing instruments relevant to supporting start-up of cooperation with the same type of business companies

\begin{tabular}{|l|c|}
\hline $\begin{array}{l}\text { Support for infrastructure to develop an efficient } \\
\text { transport system }\end{array}$ & 4.2 \\
\hline $\begin{array}{l}\text { Grant support for starting up new intermodal } \\
\text { services }\end{array}$ & 3.9 \\
\hline $\begin{array}{l}\text { Support for European research and development } \\
\text { of intermodal transport solutions and waterborne } \\
\text { transport }\end{array}$ & 3.7 \\
\hline $\begin{array}{l}\text { Support for shifting freight from roads to other } \\
\text { modes of transport }\end{array}$ & 3.7 \\
\hline
\end{tabular}

Table 4. Technical / logistics aspects relevant to sharing by cooperating with other companies from the same type of business

\begin{tabular}{|l|l|}
\hline Container terminals/warehouses & 4.3 \\
\hline Trailer transshipment equipment & 3.9 \\
\hline Innovative transshipment equipment & 3.8 \\
\hline Bulk transshipment equipment & 3.8 \\
\hline
\end{tabular}

Table 5. Benefit from joint facilitated cooperation with other companies from the same type of business

\begin{tabular}{|l|l|}
\hline Costs saving & 4.3 \\
\hline Economies of scale & 4.3 \\
\hline Added value to the services & 4.0 \\
\hline Frequency of services & 4.0 \\
\hline
\end{tabular}

\section{Conclusions}

1. The following benefits are most important in working within the logistics centre according to German and Denmark experience: intermodality benefit, forwarders impact, IT Solutions, new transport flows due to synergy, better supply chain management, additional services, cost sharing, economies of scale, quality of the services, know-how, joint marketing impact, increasing of third-party logistics services.

2. The barriers for the establishment of a logistics centre are internal and external. Internal ones are related to the point of view of logistics centre users and its business concept requirements. External barriers are long duration of planning process, pressure to land use for other purposes and problems caused by legislation. Unsolved question of land repatriation in Lithuania and missing of transport policy related to promotion of logistics centres are also strong barriers.

3. The survey in Lithuania shows the following facts. The three strongest motives for cooperation with the same type of business companies within the logistics centre could be (a) economies of scope, (b) need for resources and (c) economies of scale. The three most important benefits/profits from cooperation with the same type of business companies within the logistics centre could be (a) multimodal benefits- interaction of different transport modes, (b) growth of cargo volumes and (c) new additional services. The most expectative financing instrument relevant to supporting start-up of cooperation with the same type of business companies is the support for infrastructure to develop an efficient transport system. The three most expectative technical / logistics aspects relevant to sharing by cooperating with other companies from the same type of business within the logistics centre are (a) container terminals/warehouses, (b) trailer transhipment equipment and (c) innovative transhipment equipment. The most expectative benefit from joint facilitated cooperation with other companies from the same type of business within the logistics centre is (a) costs saving, (b) economies of scale, (c) added value to the services. 


\section{References}

1. BENTZEN, K.; BENTZEN, L.; KAPETANOVIC, E. H.; HEIKKILÄ, L. Case study on strategic business and commercial aspects of the networks of ports, logistics centres and other operators. Centre for Maritime Studies, University of Turku, Finland, 2005.

2. Logistics centres directions for use. Europlatforms EEIG. 2004. 17 p.

3. White paper - European transport policy for 2010: time to decide, COM (2001) 0370. Luxembourg: Office for Official Publication of the European Communities, 2001. $119 \mathrm{p}$.

4. LEMOINE, W.; DAGNAES, L. Globalisation strategies and business organisation of a network of logistics service providers. International Journal of Physical Distribution \& Logistics Management. Bradford: Emerald Group Publishing Limited, 2003, Vol 33, No 3, p. 209228.

5. SAUVAGE, T. The relationship between technology and logistics third-party providers. International Journal of Physical Distribution \& Logistics Management. Bradford: Emerald Group Publishing Limited, 2003, Vol 33, No 3, p. 236-253.

6. FUJIMOTO, H. Collaborative networking in a multistage industrial channel. International Journal of Physical Distribution \& Logistics Management. Bradford: Emerald Group Publishing Limited, 2003, Vol 33, No 3, p. 229-235.

7. BALLOU, R. H. Business logistics management. 4th Edition. Upper Saddle River: Prentices-Hall International Editions, 1999. $681 \mathrm{p}$.

8. PALŠAITIS, R.; BAZARAS, D. Analysis of the prospectives of intermodal transport and logistics centres in Lithuania. Transport, 2004, Vol 19, No 3, p. 119-123.

9. ŠAKALYS, A.; PALŠAITIS, R. Development of intermodal transport in new European Union states. Transport, 2006, Vol 21, No 2, p. 148-153.

10. BAZARAS, D.; PALŠAITIS; R. Multimodal approach to the international transit transport. Transport, 2003, Vol 18, No 6, p. 248-254.

11. van LAARHOVEN, P.; BERGLUND, M.; PETERS, M. Third-party logistics in Europe - five years later. International Journal of Physical Distribution \& Logistics Management. Bradford: Emerald Group Publishing Limited, 2000, Vol 30, No 5, p. 425-442.

12. BURCHACZ, M.; KASZUBOWSKI; D. Barriers regarding logistics centres establishment \& development in the Baltic Sea Region. Maritime Institute in Gdansk, Poland, 2005. $24 \mathrm{p}$. 